\title{
Modelling impairment of evoked gamma range oscillations in schizophrenia
}

\author{
Christoph Metzner $^{1 *}$, Achim Schweikard ${ }^{1}$, Bartosz Zurowski \\ From 24th Annual Computational Neuroscience Meeting: CNS*2015 \\ Prague, Czech Republic. 18-23 July 2015
}

\begin{abstract}
Abnormal oscillatory activity in schizophrenia has been found in a wide range of experimental paradigms [1]. For example, schizophrenic patients show reduced evoked gamma activity, which has been associated with negative symptoms, and increased spontaneous gamma activity, which has been associated with positive symptoms [2]. However, the underlying mechanisms remain elusive. Here we investigated the impact of circuit abnormalities on oscillatory activity in the gamma range $(>30 \mathrm{~Hz}$ ) by simulating auditory entrainment in an established computational model of the primary auditory cortex [3]. Auditory click entrainment experiments showed that for schizophrenic patients EEG/MEG power decreased at $40 \mathrm{~Hz}$ and increased at $20 \mathrm{~Hz}$ in response to $40 \mathrm{~Hz}$ drive but no differences between were visible in response to $30 \mathrm{~Hz}$ drive $[4,5]$.
\end{abstract}

Here we used the primary auditory cortex model from Beeman [3] and simulated click train stimulation at $40 \mathrm{~Hz}$, to investigate gamma entrainment deficits, and at $30 \mathrm{~Hz}$ as a control condition. Without alterations the model entrained at the driving frequency of 30 and $40 \mathrm{~Hz}$, respectively. Similar to previous approaches [6], however, focusing on evoked rather than spontaneous activity, we next explored the effects of (1) connectivity disturbances (reduced (a) recurrent excitation, (b) pyramidal cell input and (c) total connectivity), (2) prolonged GABAergic decay time constant, and (3) reduced inhibitory output.

All three interventions in connectivity $(1 \mathrm{a}-\mathrm{c})$ led to an increase in $40 \mathrm{~Hz}$ power for $40 \mathrm{~Hz}$ drive, contrary to human EEG/MEG experiments. A prolonged GABAergic decay time constant produced a reduction of power at 40 $\mathrm{Hz}$ and an increase in power at $20 \mathrm{~Hz}$, for the $40 \mathrm{~Hz}$ drive,

\footnotetext{
* Correspondence: metzner@rob.uni-luebeck.de

'Institute for Robotics and Cognitive Systems, University of Luebeck, 23538 Luebeck, Germany

Full list of author information is available at the end of the article
}

which concurs with [4,5]. Furthermore, for the $30 \mathrm{~Hz}$ drive, no differences to the standard model were observed. Reduction of inhibitory output led to decreases in power at $40 \mathrm{~Hz}$ for $40 \mathrm{~Hz}$ drive but no increases at $20 \mathrm{~Hz}$. In the $30 \mathrm{~Hz}$ drive condition, a decrease was visible, in contrast to experimental data $[4,5]$.

In conclusion, only prolonged GABAergic decay time constants (2), but not interventions (1) and (3) led to changes in entrainment comparable to experimental evidence in agreement with previous modeling approaches [5].

Our simulations suggest that prolonged time constants at GABAergic synapses might play a key role in abnormal evoked gamma rhythms in schizophrenia. However, since we only investigated one intervention at a time, further studies are needed to investigate the complex interactions of these circuit abnormalities. Furthermore, it remains unclear if the same mechanism also underlies increased spontaneous gamma activity in schizophrenia.

\section{Authors' details}

${ }^{1}$ Institute for Robotics and Cognitive Systems, University of Luebeck, 23538 Luebeck, Germany. ${ }^{2}$ Department of Psychiatry, University of Luebeck, Schleswig-Holstein, 23538 Luebeck, Germany.

Published: 18 December 2015

\section{References}

1. Gonzalez-Burgos G, Lewis DA: GABA neurons and the mechanisms of network oscillations: implications for understanding cortical dysfunction in schizophrenia. Schizophrenia Bulletin 2008, 34(5):944-961.

2. Gordon E, Williams L, Haig AR, Wright J, Meares RA: Symptom profile and "gamma" processing in schizophrenia. Cognitive Neuropsychiatry 2001, 6:7-19,2001.

3. Beeman D: A modeling study of cortical waves in primary auditory cortex. BMC Neuroscience 2013, 14(Suppl 1):P23.

4. Kwon JS, O'Donnell BF, Wallenstein GV, Greene RW, Hirayasu Y, Nestor PG, Hasselmo ME, Potts GF, Shenton ME, McCarley RW.: Gamma frequencyrange abnormalities to auditory stimulation in schizophrenia. Archives of General Psychiatry 1999, 56(11):1001-1005.

5. Vierling-Claassen D, Siekmeier P, Stufflebeam S, Kopell N: Modeling gaba alterations in schizophrenia: a link between impaired inhibition and 
altered gamma and beta range auditory entrainment. Journal of Neurophysiology 2008, 99(5):2656-2671.

6. Spencer KM: The functional consequences of cortical circuit abnormalities on gamma oscillations in schizophrenia: insights from computational modeling. Frontiers in Human Neuroscience 2009, 3.

doi:10.1186/1471-2202-16-S1-P305

Cite this article as: Metzner et al:: Modelling impairment of evoked gamma range oscillations in schizophrenia. BMC Neuroscience 201516 (Suppl 1):P305.

Submit your next manuscript to BioMed Central and take full advantage of:

- Convenient online submission

- Thorough peer review

- No space constraints or color figure charges

- Immediate publication on acceptance

- Inclusion in PubMed, CAS, Scopus and Google Scholar

- Research which is freely available for redistribution

Submit your manuscript at www.biomedcentral.com/submit
C Biomed Central 